\title{
Regulation of human subcutaneous adipocyte differentiation by EID1
}

\author{
Diana Vargas ${ }^{1}$, Noriaki Shimokawa ${ }^{2}$, Ryosuke Kaneko³, Wendy Rosales', \\ Adriana Parra ${ }^{1}$, Ángela Castellanos ${ }^{1}$, Noriyuki Koibuchi ${ }^{2}$ and Fernando Lizcano' \\ ${ }^{1}$ Center of Biomedical Research (CIBUS), Universidad de La Sabana, Km. 7 Autopista Norte de Bogota, \\ 140013 Chia, Colombia \\ ${ }^{2}$ Department of Integrative Physiology, Gunma University, Maebashi, Japan \\ ${ }^{3}$ Institute of Experimental Animal Research, Gunma University, Maebashi, Japan
}

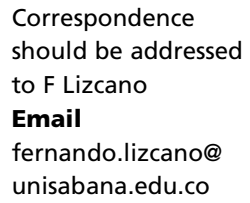

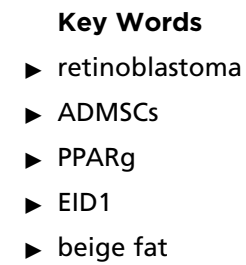

Journal of Molecular Endocrinology (2016) 56, 113-122

\section{Introduction}

Obesity and its associated metabolic diseases, such as type 2 diabetes mellitus, hypertension, and cardiovascular disease, are increasing in prevalence due to a combination of environmental factors and genetic variations (van Dijk et al. 2014, Robbins et al. 2014). Recent research has led to a deeper understanding of adipocyte physiology. These advances may provide important clues to find effective options for treating obesity (Nedergaard et al. 2011, $\mathrm{Wu}$ et al. 2013). Adipocytes develop from adipose mesenchymal stem cells (ADMSCs), which are primarily of mesodermal origin. However, the specific localizations of fat cells and their associated differential gene expression patterns, thermogenic capacities, and abilities to induce vascular complications suggest that they have diverse origins. Indeed, various types of adipocytes were recently identified in adults (Sidossis \& Kajimura 2015). In contrast with white adipose tissue (WAT), brown adipose tissue (BAT) is specialized for the dissipation of chemical energy in the form of heat, a process dependent on mitochondrial uncoupling protein 1 (UCP1). Adult humans lack classical BAT but possess a subset of cold-inducible beige adipocytes in their WAT. The recognition of the phenotypic plasticity

Published by Bioscientifica Ltd. 
of beige fat cells in adults has increased interest in the development of potential drugs to treat obesity and metabolic diseases (Cannon \& Nedergaard 2004, Rosen \& Spiegelman 2014). The origin of beige fat is unclear, but the progenitors of several types of these cells are similar to progenitors of white adipocytes (Seale et al. 2008, Wu et al. 2012). Thus, subsets of the predominant white fat cells in adults may be converted to the more metabolically active beige fat cells (Sharp et al. 2012, Lidell et al. 2013, Sidossis $\&$ Kajimura 2015). Although the molecular mechanisms underlying this process remain unclear, producing metabolically active, physiological beige cells from adult white cells represents an interesting challenge (Cypess et al. 2009, Vitali et al. 2012, Berry \& Rodeheffer 2013, Lidell et al. 2014).

The differentiation of beige adipocytes from precursor cells and WAT beiging transdifferentiation from white adipocytes is regulated by many factors, including the bone morphogenetic protein 7/PR domain containing protein 16/peroxisome proliferator-activated receptor gamma (PPARg) coactivator 1 alpha (BMP7/PRDM16/ PGC1 $\alpha$ ) axis (Seale et al. 2008, Seale 2015). Moreover, agonists of nuclear receptor PPARg and inhibitors of retinoblastoma protein $(\mathrm{pRb})$ play important roles in the development and activation of beige cells (Auffret et al. 2012, Ohno et al. 2012, Harms \& Seale 2013). The inactivation of $\mathrm{pRb}$ may increase levels of PGC1 $\alpha$ (Hallenborg et al. 2009, Mercader et al. 2009, Lee et al. 2013). Studies in animal models show that the inactivation of $\mathrm{pRb}$ in adipose tissue increases mitochondrial activity levels and induces resistance to obesity (Hansen et al. 2004a,b, Khidr \& Chen 2006, Dali-Youcef et al. 2007, Calo et al. 2010, Auffret et al. 2012).

In searching for molecules that modulate adipogenesis, we identified EP300-interacting inhibitor of differentiation (EID1; Lizcano \& Vargas 2010), which was originally described as an inhibitor of muscle cell differentiation (MacLellan et al. 2000, Miyake et al. 2000). EID1 reduces the transactivation of several nuclear receptors, including glucocorticoid receptor, thyroid receptor, and estrogen receptor (Miyake et al. 2000, Bavner et al. 2002). However, little is known regarding the role of EID1 in the regulation of PPARg. EID1 is thought to mediate small heterodimer partner (SHP) repression (Tabbi-Anneni et al. 2010), with SHP being a predominant activator of PPARg (Nishizawa et al. 2002). EID1 contains an $\mathrm{LxCxE}$ sequence in its C-terminal domain, allowing it to bind to pRb (Wen \& Ao 2001), and an acidic site that inhibits p300-CBP coregulators. By inactivating $\mathrm{pRb}$ and reducing PPARg activity, EID1 activates the expression of thermogenic proteins in 3T3-L1 cells (Lizcano \& Vargas 2010). These findings suggested that EID1 may play an important role in the differentiation of brown and beige adipocytes.

This study was designed to assess the effects of EID1 on both mesenchymal cells and mature adipocytes induced from subcutaneous fat of a group of healthy women. EID1 overexpression promoted the activation of beige adipocytes, indicating that EID1 may be a critical factor in regulating brown/beige adipocyte differentiation. Moreover, EID1 may be a therapeutic target for obesity by stimulating the conversion of white to beige adipocytes, thus increasing energy expenditure.

\section{Subjects and methods}

\section{Subjects}

Subcutaneous fat samples were obtained from ten healthy women between 20 and 40 years of age who underwent abdominoplasty. Each woman had a BMI between 23 and $25 \mathrm{~kg} / \mathrm{m}^{2}$ and had not been treated with any drugs for at least 3 months prior to sampling. Their lipid profiles and blood glucose levels were normal. All subjects received detailed information regarding the purpose of the study and provided written informed consent. The study protocol was approved by the Ethics Committee of La Sabana University.

\section{Plasmids}

PPARg was cloned into the Sall site of the pSV.SPORT1 vector. The PPRE-Luc and Gal4-PPARg-LBD constructs were previously described (Spiegelman 1998). EID1 was cloned into the expression vector pcDNA3.1-T7 at the BamHI and EcoRI restriction sites. EID1-157 was generated by PCR using the primers 5'-GTGAATTCCACAAT GTCGGAAATGGCTG-3' (forward) and 5'-AGCAATCTGATCAAACGGGGTCTTCTC-3' (reverse) and inserting the PCR product into the vector TOPO pcDNA 3.1 (Life Technologies).

The $\Delta$ EID1 mutant lacks both the C-terminal domain (LxCxE) that allows the protein to bind to $\mathrm{pRb}$ and the acidic residues 53-63 and 92-115 that facilitate binding to p300 (Miyake et al. 2000). The p300 plasmid was constructed by inserting the sequence encoding p300 into the NotI and HindIII sites in the NHA-CMV vector. Construction of the SRC1 and PRIP/nuclear receptor coactivator 6 (NCOA6) plasmids was previously described (Onate et al. 1995, Zhu et al. 2000). The $5 \times$ UAS reporter

Published by Bioscientifica Ltd. 
was cloned into the BamHI and HindIII restriction sites in the PT109 vector, which contained the thymidine kinase promoter coupled to the luciferase gene (Takeshita et al. 1997). To construct the aP2-EID1-woodchuck hepatitis virus post-transcriptional regulatory element (WPRE) plasmid, a $5.4 \mathrm{~kb}$ region identified as the aP2 promoter was amplified by PCR from mouse genomic DNA using Tks Gflex DNA Polymerase (Takara, Otsu, Shiga, Japan), according to the manufacturer's instructions, and specific primers (Imai et al. 2001) also containing 5' SalI and $3^{\prime}$ NheI restriction sites, and the product was cloned into pCR-Blunt II TOPO (Invitrogen). The previously described WPRE sequence (Zufferey et al. 1999) was digested with EcoRI and inserted into pCX-EGFP (Clontech), generating pCX-WPRE. EID1 was obtained by PCR using the primers 5'-ACAATGTCGGAAATGGCTG-3' (forward) and 5'-GAGATTATTGATAGAGAGTAG-3' (reverse), containing NheI and SacI ends respectively, and the product was inserted into pCX-WPRE, resulting in pCX-EID1-WPRE. The aP2 promoter was cloned upstream of pCX-EID1 between the $5^{\prime}$ Sall and $3^{\prime}$ NheI sites, generating the $7.2 \mathrm{~kb}$ pCX-aP2-EID1-WPRE plasmid.

\section{Cell culture}

U2OS cells obtained from the American Tissue Culture Collection (ATCC, Manassas, VA, USA) were cultured in DMEM supplemented with $10 \%$ fetal bovine serum (FBS) (Gibco, Life Technologies) and 1\% penicillin/streptomycin at $37{ }^{\circ} \mathrm{C}$ in an atmosphere containing $5 \% \mathrm{CO}_{2}$. Primary cultures were prepared from $20 \mathrm{~g}$ abdominal subcutaneous adipose tissue. Fat samples were washed with PBS, and fibrous material and all visible blood vessels were removed. The samples were incubated with $250 \mathrm{U} / \mathrm{ml}$ collagenase type I, $20 \mathrm{mg} / \mathrm{ml} \mathrm{BSA}$, and $60 \mu \mathrm{g} / \mathrm{ml}$ gentamycin in PBS for $90 \mathrm{~min}$ at $37^{\circ} \mathrm{C}$ while stirring. The samples were centrifuged at $200 \mathrm{~g}$ for $10 \mathrm{~min}$, and the pellet was suspended in lysis buffer, consisting of erythrocytes, $154 \mathrm{mM}$ ammonium chloride $\left(\mathrm{NH}_{4} \mathrm{Cl}\right), 5.7 \mathrm{mM}$ monobasic potassium phosphate $\left(\mathrm{K}_{2} \mathrm{HPO}_{4}\right)$, and $0.1 \mathrm{mM}$ EDTA, $\mathrm{pH}$ 7.3, for $10 \mathrm{~min}$. This mixture was filtered through a $150 \mu \mathrm{m}$ pore size nylon mesh, followed by centrifugation at $200 \boldsymbol{g}$ for $10 \mathrm{~min}$. The cell pellet was suspended at 10000 cells $/ \mathrm{cm}^{2}$ in growth medium, consisting of DMEM/F12 plus $10 \% \mathrm{FBS}$ and $50 \mathrm{mg} / \mathrm{ml}$ gentamicin. After $24 \mathrm{~h}$, the cells were washed and resuspended in PM4 proliferation medium (DMEM/F12, 2.5\% FBS, $1 \mathrm{ng} / \mathrm{ml}$ basic fibroblast growth factor, $10 \mathrm{ng} / \mathrm{ml}$ epidermal growth factor, and $8.7 \mu \mathrm{M}$ insulin; Skurk et al. 2007) until they became $100 \%$ confluent and had differentiated into mature adipocytes.
These cells were identified by incubation with antibody to CD34 and sorting by flow cytometry (Rodeheffer et al. 2008). Human mesenchymal cells were differentiated into adipocytes by incubation for $72 \mathrm{~h}$ in DMEM/F12 containing $66 \mathrm{nM}$ insulin, $1 \mathrm{nM}$ triiodo-L-thyronine, $10 \mu \mathrm{g} / \mathrm{ml}$ transferrin, $0.5 \mathrm{mM}$ isobutylmethylxanthine, $1 \mu \mathrm{M}$ dexamethasone, and $2 \mu \mathrm{M}$ rosiglitazone. The medium was replaced with basal medium containing equal concentrations of insulin, triiodo-L-thyronine, and transferrin, and the cultures were grown for an additional 10 days, with the medium being replaced every 3 days (Skurk et al. 2007).

\section{Transfections}

Functional assays for luciferase activity were performed using the U2OS cell line. The cells were transfected at $80 \%$ confluence using Lipofectamine 2000 (Life Technologies) with $0.85 \mu \mathrm{g}$ PPRE-Luc, $0.5 \mu \mathrm{g}$ CMV-b-galactosidase, $0.1 \mu \mathrm{g}$ PPARg, $0.2 \mu \mathrm{g}$ EID1, and $0.1 \mu \mathrm{g}$ of each of the coactivators. After $24 \mathrm{~h}$, the cells were treated with $1 \mu \mathrm{M}$ rosiglitazone or DMSO as vehicle. After an additional $24 \mathrm{~h}$, the cells were lysed, and both luciferase activity and $\beta$-galactosidase levels were measured. The results were reported as fold changes in luciferase gene activity compared with the empty expression vector, which was used as a control.

Transfections of the ADMSCs with the EID1 expression vector and with empty vector (pcDNA 3.1) were performed using Lipofectamine LTX (Life Technologies), according to the manufacturer's instructions. Briefly, $24 \mathrm{~h}$ before transfection, $0.2 \times 10^{6}$ cells were subcultured in each well of a 24-well culture plate containing growth medium that was free of antibiotics. The transfection mixture was prepared in $50 \mathrm{ml}$ Opti-MEM medium (Life Technologies) with $0.5 \mu \mathrm{g}$ DNA and $0.5 \mu$ l Plus Reagent; Lipofectamine was added to $50 \mathrm{ml}$ Opti-MEM medium at a 1:4 DNA:Lipofectamine ratio. After $20 \mathrm{~min}$, the mixture was added to the cells. The medium was removed after $4 \mathrm{~h}$ and replaced with complete growth medium. After $48 \mathrm{~h}$, differentiation was induced for 10 days, and triglyceride (TG) analysis was performed as previously described (Lizcano \& Vargas 2010). For protein expression analysis, total protein was isolated $48 \mathrm{~h}$ after transfection, which corresponded to day 0. Differentiation was induced, and protein extracts were obtained after 3 and 6 days.

To determine the effects of EID1 on mature adipocytes, ADMSCs were induced to differentiate into adipocytes. pCX-aP2-EID1-WPRE and pCX-WPRE as a

Published by Bioscientifica Ltd. 
control were overexpressed by Lipofectamine LTX using a reverse transfection method as described (Kilroy et al. 2009). The transfection mixture was prepared in $100 \mu \mathrm{l}$ Opti-MEM with $2.5 \mu \mathrm{g}$ DNA and $2.5 \mu \mathrm{l}$ Plus Reagent. Lipofectamine was diluted in $100 \mu \mathrm{l}$ Opti-MEM at a 1:5 ratio of DNA:Lipofectamine. After $20 \mathrm{~min}, 200 \mu \mathrm{l}$ solution was added to $1.5 \times 10^{6}$ fat cells suspended in each well of a six-well plate. After $4 \mathrm{~h}$, the medium was replaced by complete differentiation medium containing $1 \mu \mathrm{M}$ rosiglitazone. The cells were maintained in growth medium for 24 or $48 \mathrm{~h}$.

\section{Flow cytometry}

ADMSCs $\left(5 \times 10^{5}\right)$ transfected with the indicated plasmids were harvested and incubated with a 1:100 dilution of anti-CD137-PE (4B4-1; BD Biosciences, Piscataway, NJ, USA) or control isotype IgG1 MABs for $20 \mathrm{~min}$ in the dark. After several washes with PBS, the samples assessed by flow cytometry (fluorescence-activated cell sorting; Roche), with the results analyzed by FlowJo Software (Treestar, Ashland, OR, USA).

\section{QRT-PCR}

Total RNA from cultured human ADMSCs was isolated $24 \mathrm{~h}$ after EID1 transfection and 3 and 6 days after induction of differentiation. RNA was extracted from cells using the High Pure RNA Isolation Kit (Roche Diagnostics), according to the manufacturer's instructions. First-strand cDNA was synthesized from $500 \mathrm{ng}$ of total RNA using Transcriptor First Strand cDNA Synthesis Kits (Roche Diagnostics). PCRs were performed using primers specific for human PGC1 $\alpha$ (forward, 5'-CTGTGTCACCACCCAAATCCTTAT-3'; reverse, 5'-TGTGTCGAGAAAAGGACCTTGA-3'), human UCP1 (forward, 5'-GTGTGCCCAACTGTGCAATG3'; reverse, 5'-CCAGGATCCAAGTCGCAAGA-3'), human CITED1 (forward, 5'-CAACCTTGCGGTGAAAGATCG-3'; reverse, 5'-GGAGAGCCTATTGGAGATCCC-3'), and human GAPDH (forward, 5'-ACCCACTCCTCCACCTTTGAC-3'; reverse, 5'-TGTTGCTGTAGCCAAATTCGTT-3') and FastStart Essential DNA Green Master (Roche Diagnostics). The levels of expression of PGC1 $\alpha$, UCP1, and CITED1 were normalized relative to the levels of expression of GADPH in the same samples.

\section{SiRNA}

Synthetic siRNA oligonucleotides were designed and produced by Invitrogen. After testing three sequences to determine the most effective sequence for blocking EID1 expression, the sequence used was 5'-GAGAGACAG UGAGAUCCUGCAGGAU-3', identified as siRNAEID1/2. As a control, cells were treated with Lipofectamine alone or siRNAEID1/1, which did not affect EID1 expression. Primary cells were transfected at $90 \%$ confluence with $30 \mathrm{nM}$ siRNA using $1.2 \mu \mathrm{l}$ Lipofectamine RNAi MAX, according to the manufacturer's instructions. After $48 \mathrm{~h}$, total protein was isolated, and EID1 and PGC1 $\alpha$ levels were evaluated.

\section{Western blot analysis}

Total protein from cultured human ADMSCs was extracted $48 \mathrm{~h}$ after EID1 transfection and 3 and 6 days later using RIPA buffer (Abcam, Cambridge, MA, USA) and $1 \mathrm{mg}$ protease inhibitors (Roche Diagnostics). Protein concentrations were quantitated using the Bradford method, and $50 \mathrm{mg}$ aliquots of proteins were denatured at $95{ }^{\circ} \mathrm{C}$ and subjected to PAGE. The proteins were electrophoretically transferred to PVDF membranes that had been pre-treated with $100 \%$ methanol for $2 \mathrm{~min}$. Membrane blocking was performed with PBS-T $(1 \times$ PBS and $0.1 \%$ Tween 20 ) containing $5 \%$ powdered skim milk. The membranes were subsequently incubated with the following antibodies: rabbit anti-PGC1 $\alpha, 1: 1000$ dilution (ab54481, Abcam); rabbit anti-UCP1, 1:1000 dilution (ab1551117, Abcam); rabbit anti-TFAM (7495), 1:1000 dilution (Cell Signaling, Beverly, MA, USA); mouse antiCITED1 (ab87978, Abcam), 1:250 dilution; and mouse anti-pRb (MAB3168, Millipore, Concord, MA, USA), 1:2000 dilution. The membranes were washed and incubated with HRP-conjugated secondary antibodies against rabbit IgG, at dilutions of 1:2000 and 1:3000 to detect expression of PGC1 $\alpha$, TFAM, and UCP1, or with HRP-conjugated anti-mouse IgG, at a dilution of 1:2000, to detect expression of CITED and pRb. Antibody binding was detected by chemiluminescence, using Crescendo Luminata Kits (EDMillipore, Darmstadt, Germany), according to the manufacturer's instructions. Images were captured and analyzed using a myECL Imager (Thermo Scientific, Rockford, IL, USA). The results were expressed as mean \pm s.e.M. and analyzed by ANOVA, with differences considered statistically significant when the $P$ value was $<0.05$.

Differences in ADMSCs transfected with pCX-aP2EID1-WPRE and pCX-WPRE were compared. Mature cells were lysed with RIPA buffer 24 and $48 \mathrm{~h}$ after transfection, and total protein extracts obtained. These extracts were electrophoresed on SDS-PAGE and electrophoretically transferred to PVDF membranes as described above.

Published by Bioscientifica Ltd. 
A

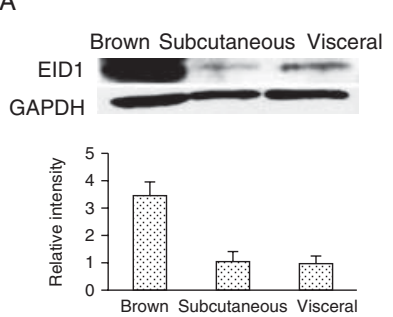

B

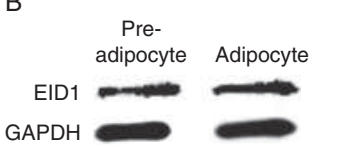

\section{Figure 1}

EID1 expression in fat cells and effects of EID1 on PPARg transactivation and coregulators. (A) Samples of intercapular, inguinal, and visceral fat were obtained from 2-month-old female Wistar rats weighing $150 \mathrm{~g}$. (B) Samples from normal women were obtained from their subcutaneous fat and ADMSCs were identified and induced to differentiate into fat cells. Protein extracts were obtained before and after 10 days of induced differentiation. (C) The Gal4-PPARg-LBD expression vector $(0.1 \mu \mathrm{g})$ was cotransfected with the $5 \times$ UAS reporter $(0.85 \mu \mathrm{g})$ and EID1 expression vector $(0.2 \mu \mathrm{g})$ in the presence or absence of rosiglitazone $(1 \mu \mathrm{M})$. After $24 \mathrm{~h}$, luciferase activity

The expression of FABP4 was assayed using rabbit anti-FABP4 antibody (ab92501, Abcam), diluted 1:1500, and HRP-conjugated rabbit IgG secondary antibody diluted 1:3000.

\section{Statistical analysis}

Cells obtained from the ten healthy women were assessed individually $(n=10)$, with data expressed as the mean \pm s.D. Results were compared by ANOVA, followed by the Bonferroni's post-hoc test. All statistical analyses were performed using SPSS Software, with a $P$ value $<0.05$ considered statistically significant. was measured. (D) U2OS cells were cotransfected with the expression plasmid encoding PPARg $(0.1 \mu \mathrm{g})$ in the presence of each of the coactivators $(0.1 \mu \mathrm{g})$, the EID1 vector $(0.2 \mu \mathrm{g})$, and the PPRE-Luc reporter $(0.1 \mu \mathrm{g})$. These cells were treated with $1 \mu \mathrm{M}$ rosiglitazone for $24 \mathrm{~h}$, after which luciferase activity was measured. Luciferase activity levels were normalized relative to that of CMV-b-galactosidase $(0.5 \mu \mathrm{g})$. These results are representative of three independent experiments with triplicate samples. ${ }^{*} P<0.05$.

\section{Results}

\section{Expression of EID1 in adipose tissue and effect of EID1 on PPARg activation}

To investigate the expression of EID1 in different types of fat, sample from intercapular, inguinal, and visceral regions was obtained from Wistar rats and total proteins were isolated. The highest levels of EID1 protein were detected in brown fat from intercapular adipose tissue, whereas inguinal and visceral fat showed low levels of EID1 (Fig. 1A). In addition, western blotting showed that EID1 protein was expressed by both precursors and adipocytes induced from subcutaneous fat (Fig. 1B).
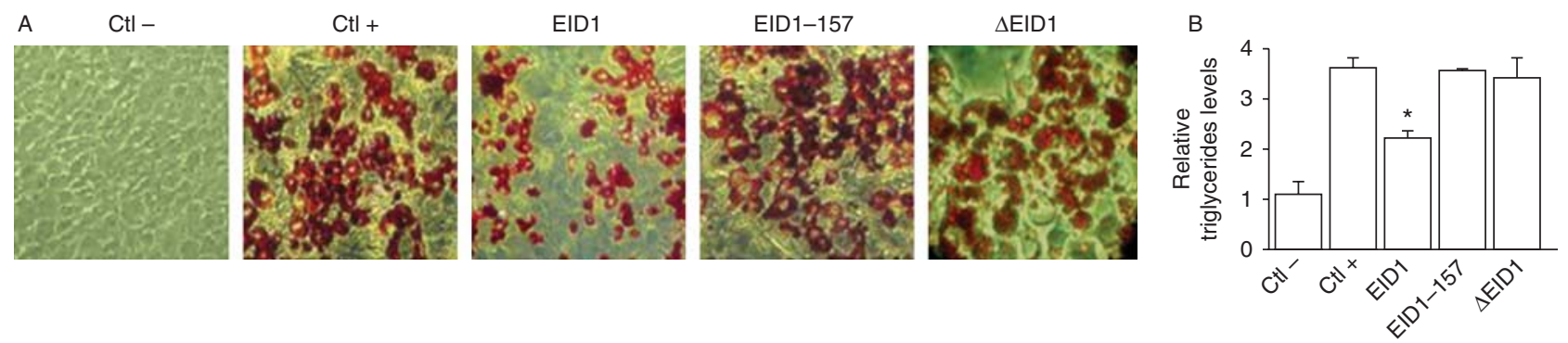

\section{Figure 2}

Overexpression of EID1 reduces lipid accumulation in ADMSCs. (A) Cells obtained from human subcutaneous adipose tissue were transfected with $0.5 \mu \mathrm{g}$ of empty vector (pCDNA 3.1), EID1 (0.5 $\mu \mathrm{g})$, EID1-157, or ÄEID1, $0.5 \mu \mathrm{l}$ of Plus Reagent and Lipofectamine LTX at a ratio of 1:4. After $48 \mathrm{~h}$, differentiation was induced. Ten days later, the cells were stained with Oil Red $\mathrm{O}$, and triglyceride concentrations were quantitated. The negative control represent cells not induced to undergo adipogenesis.
(C) 2016 Society for Endocrinology Printed in Great Britain
Positive controls included cells transfected with empty vector and induced to differentiate. ${ }^{*} P<0.05$ of mean \pm s.D. of three independent experiments conducted in triplicate. (B) Relative levels of triglycerides in ADMSC, after inducing differentiation of fat cells and transfection with different plasmids of EID1 and mutants. To quantify trigliceryde, $1 \mathrm{ml}$ of isopropanol was added for $5 \mathrm{~min}$, to distaining the fat deposits. Absorbance was measured at $510 \mathrm{~mm}$ wavelength.

Published by Bioscientifica Ltd. 
Treatment with rosiglitazone of U2OS cells cotransfected with plasmids containing Gal4-PPARg-LBD and the reporter gene EID1-5 $\times$ UAS-Luc showed that EID1 reduced PPARg activity by more than 50\% (Fig. 1C). To assess the effects of EID1 on PPARg coactivators, U2OS cells were cotransfected with the SRC1, p300 or PRIP expression vector, the PPARg plasmid, and the PPRE-Luc promoter vector. The increased PPARg activity induced by different coactivators was reduced by EID1; however, PPARg activity was significantly reduced in the presence of p300 and PRIP, but not in the presence of SRC1 (Fig. 1D).

\section{Overexpression of EID1 modulates adipogenic differentiation in ADMSCs}

EID1 reduces TG accumulation in 3T3-L1 mouse pre-adipocytes (Lizcano \& Vargas 2010). To further determine the physiological role of EID1 in adipocyte from human adipose tissue. ADMSCs, identified by CD34 flow cytometry (data not shown), were transfected with EID1 and control plasmids, with differentiation initiated $48 \mathrm{~h}$ later. Ten days later, staining and TG quantification were performed.

Consistent with reports evaluating 3T3-L1 pre-adipocytes, EID1 significantly reduced TG levels in cells isolated from human adipose tissue. $\Delta$ EID1 and EID1-157 mutants, which lack the capacity to bind to pRB and p300 respectively, had no effect on adipose cell differentiation (Fig. 2A and B). As EID1 was shown to reduce the activity of $\mathrm{pRb}$, the effect of EID1 on pRb in ADMSCs was evaluated. Total protein was isolated from these cells $48 \mathrm{~h}$ after transfection, total protein was extracted, and $\mathrm{pRb}$ expression was measured (Fig. 3A). Knockdown of EID1 with EID1 siRNA reduced the expression of PGC1 $\alpha$ (Fig. 3B).

To assess the effects influence of EID1 on thermogenic proteins, cells were stimulated to differentiate $48 \mathrm{~h}$ after transfection. Samples were collected the day induction of

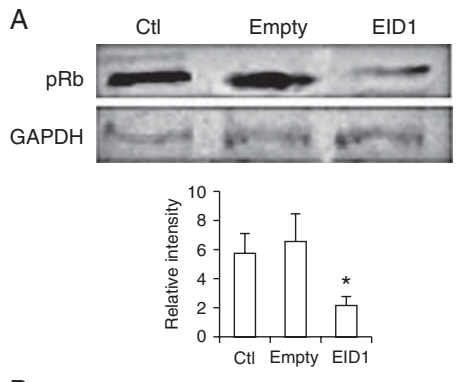

B
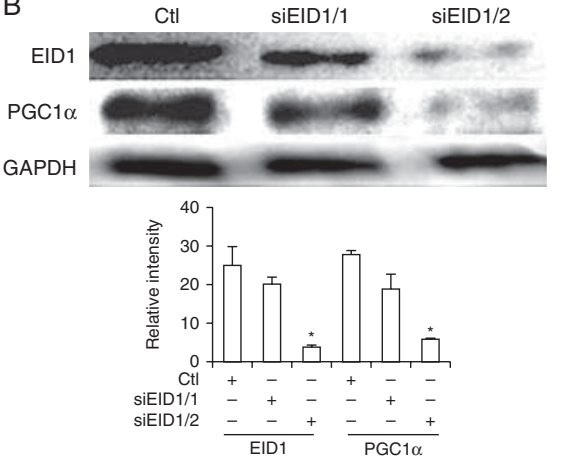
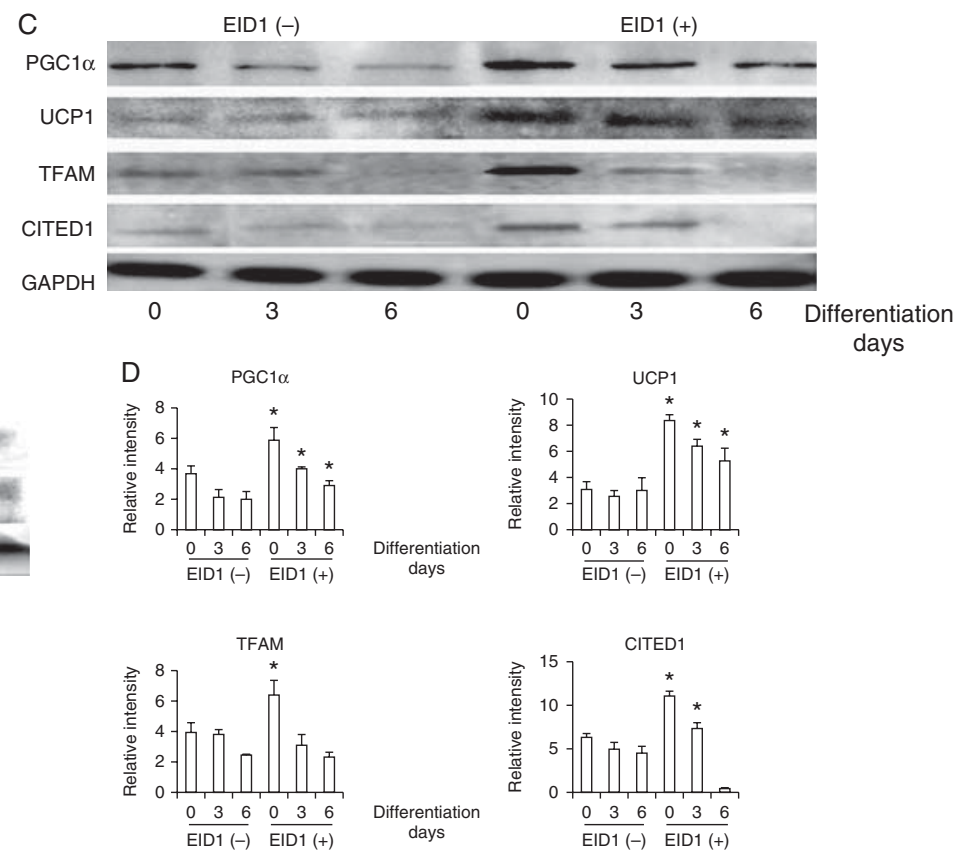

\section{Figure 3}

EID1 reduces the expression of $\mathrm{pRb}$ and increases thermogenic proteins in ADMSCs. (A) EID1 expression vector was transfected into ADMSCs. After $48 \mathrm{~h}$, total protein was isolated, and pRb was measured by western blot. Quantitative analyses were performed by the densitometry of the bands representing the different experiments. The results were compared to the control pre-adipocytes treated only with Lipofectamine LTX or to empty pcDNA3.1 vector. (B) Endogenous EID1 expression was inhibited by transfecting the ADMSCs with siRNA against EID1 using Lipofectamine RNAiMAX. EID1 inhibition was evaluated $48 \mathrm{~h}$ after transfection by western blotting to detect PGC1 $\alpha$ and EID1 levels. Control cells corresponded to cells treated with only Lipofectamine RNAiMAX and siRNAEID1/1, which had no effects on the inhibition of EID1. The reduction of EID1 was accompanied by the decreased expression of PGC1 $\alpha$ as shown by siRNA1/2. (C) ADMSCs were cotransfected as indicated in Fig. 2 , and total protein was recovered at day 0 ( $48 \mathrm{~h}$ post-transfection), at which point differentiation was induced. The protein extracts were obtained on the indicated days. Using western blotting, the expression levels of the PGC1 $\alpha$, UCP1, CITED1, and TFAM proteins were measured. EID1 ( $)$ corresponds to cells transfected with the empty pcDNA-3.1 vector. (D) The relative intensity levels were determined by the densitometry of the bands. The data are expressed as the mean \pm s.D. $(n=10)$, and $* P<0.05$ that correspond to a significant difference in relation to each day and the effects of EID1 on the proteins detected by the western blot analysis (PGC1 $\alpha$, UCP1, and TFAM CITED1). The data were normalized to GAPDH.

Published by Bioscientifica Ltd. 


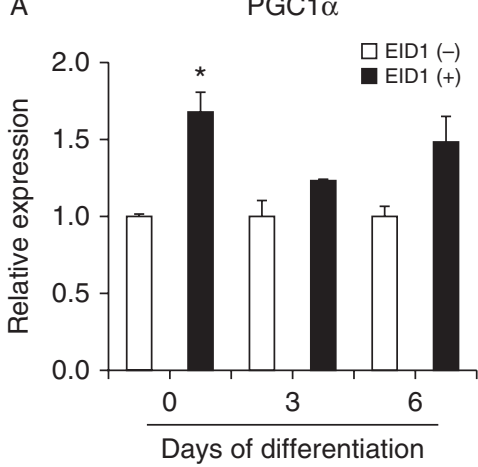

$B$

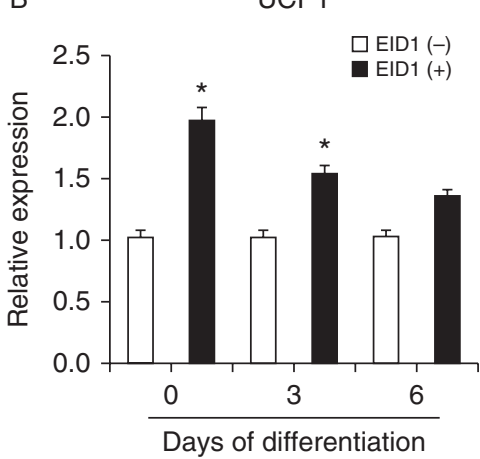

C CITED

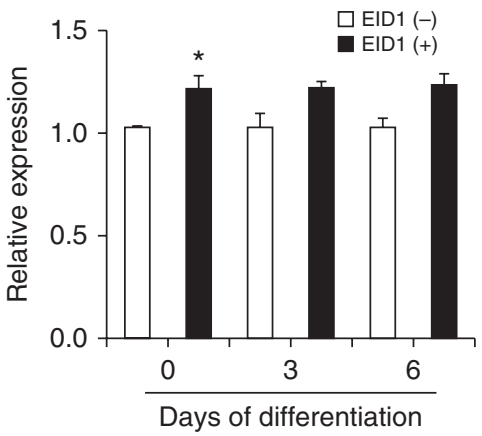

Figure 4

EID1 increases the expression of genes involved in thermogenesis. EID1 was transfected into ADMSCs, as indicated in Fig. 2. At $24 \mathrm{~h}$ after transfection, differentiation was induced and total RNA was isolated. The levels of expression of (A) PGC1 $\alpha$, (B) UCP1, and (C) CITED were measured.

differentiation was started, with additional samples obtained 3 and 6 days later. EID1 significantly upregulated UCP1, mitochondrial PGC1 $\alpha$ and TFAM marker expression levels compared with cells treated with empty vector (Fig. 3C). In addition, the expression of a specific marker of beige cells, CITED1 (Fig. 3C), was increased, and surface expression of CD137 (Fig. 3E) was observed (Wu et al. 2012). These proteins are characteristic of the beige adipocyte phenotype and are not expressed in brown adipocytes. Quantitative RT-PCR assays for the expression of specific RNAs showed that the levels of
EID1 (-) corresponds to cells transfected with empty vector pCDNA 3.1. Data are expressed as mean \pm s.D. and the asterisk indicates statistically significant differences $(P<0.05)$ in relation to each day and the presence or absence of EID1. GAPDH was used as a reference.
A

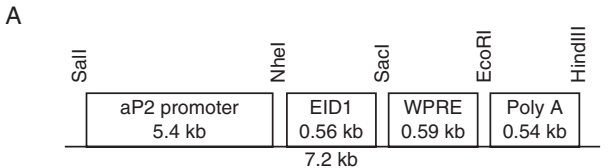

B

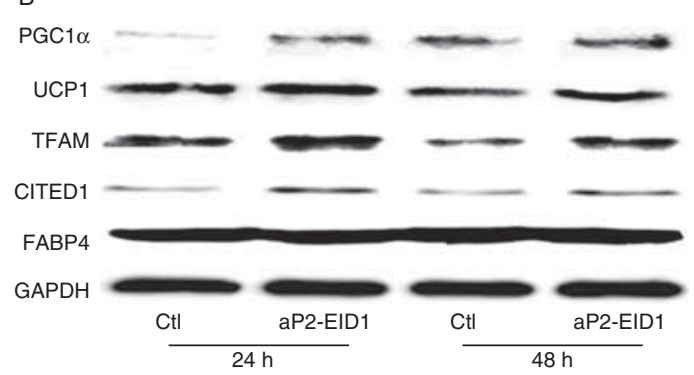

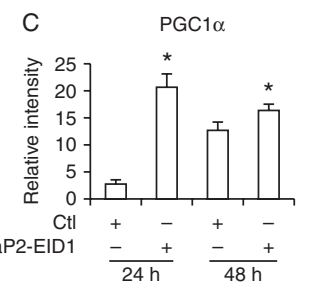
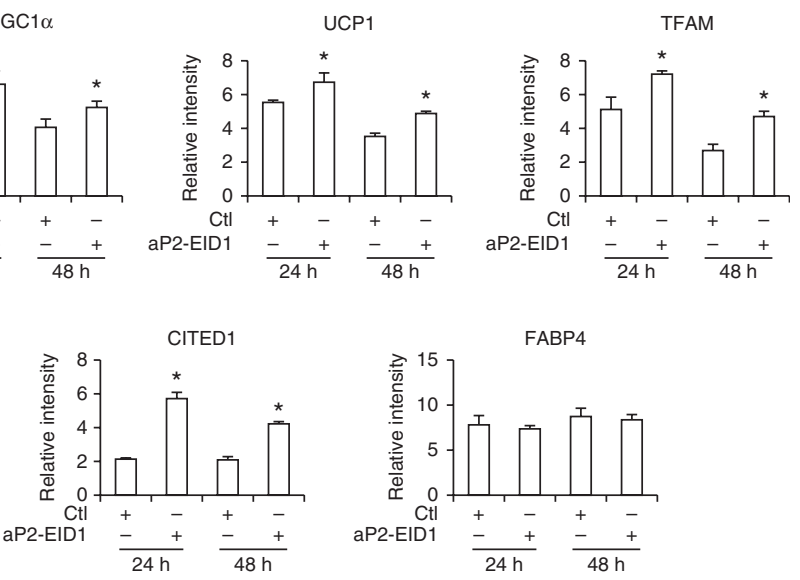

Figure 5

EID1 induces the beige phenotype in mature fat cells. (A) Diagram of the PCX aP2-EID1-WPRE transgene. The aP2 promoter $(0.56 \mathrm{~kb})$ was located upstream of the EID1 CDNA, and the WPRE gene sequence $(0.54 \mathrm{~kb})$ was downstream of aP2-EID1. (B) ADMSCs induced to undergo adipogenesis were transfected with the pCX-WPRE vector $(2.5 \mu \mathrm{g})$ or aP2-EID1-WPRE vector and Lipofectamine LTX at 1:5 ratio. At 24 or $48 \mathrm{~h}$ after transfection,
(C) 2016 Society for Endocrinology Printed in Great Britain expression of PGC1 $\alpha, \mathrm{UCP} 1$, and CITED1 were increased (Fig. 4A and B).

\section{EID1 induces the beige phenotype in mature fat cells}

To evaluate the effects of EID1 on mature white adipose cells differentiated from ADMSCs, these cells, expressing FABP4, were transfected with the pCX-aP2-EID1-WPRE transgene or the pCX-WPRE control. Proteins were extracted after 24 and $48 \mathrm{~h}$, and the levels of expression levels of proteins and thermogenic beige phenotype 
markers were measured. Treatment of differentiated cells with EID1 increased the levels of PGC1 $\alpha$, UCP1, and TFAM mRNAs and significantly increased the level of expression of CITED1, a marker of beige adipose cells (Fig. 5B and C).

\section{Discussion}

The results of this study showed that EID1 modulates the differentiation of adipocyte precursors, inducing those of the brown/beige lineage. In addition, EID1 can induce the conversion of white to beige adipocytes. Increased levels of EID1 in ADMSCs increased the expression of mitochondrial proteins and regulators of thermogenesis, such as UCP1, TFAM, and PGC1 $\alpha$. EID1 was initially described as an inhibitor of the differentiation of muscle cells (MacLellan et al. 2000, Miyake et al. 2000), and we recently showed that EID1 reduces the differentiation of adipocytes from 3T3-L1 pre-adipocytes (Lizcano \& Vargas 2010). Treatment of ADMSCs obtained from a group of healthy women with EID1 induced adipose cell differentiation toward more metabolically active fat cells, with increased levels of expression of UCP1 and CITED1, which are specific markers of beige cells (Sharp et al. 2012). EID1 partially reduced the activity of PPARg by inhibiting the p300 cofactor, which may explain the reduced accumulation of lipids in white adipose cells. However, these findings suggest that increases in the thermogenic protein UCP1, CITED1, and CD137 during the ADMSC differentiation process may result from a reduction in $\mathrm{pRb}$ activity. These changes indicate that EID1 generates the beige phenotype during the process of differentiation of the multipotent cells used in this work (Zeve et al. 2009, Orbay et al. 2012). ADMSCs may express UCP1 after several days of treatment with rosiglitazone (Elabd et al. 2009). However, this study showed that rosiglitazone induced UCP1 expression during the differentiation process. However, transfection of EID1 resulted in significant differences in the levels of UCP1 protein.

Using an expression vector containing EID1 under the control of the aP2 promoter allowed the effects of EID1 on mature white adipocytes to be evaluated. The increased expression levels of thermogenic and mitochondrial proteins and of CITED1 suggest that EID1 may induce the beiging of white fat cells. The most likely mechanism of development of this beige phenotype is through an indirect increase in PGC1 $\alpha$ activity, followed by the inhibition of $\mathrm{pRb}$. This latter protein plays an important role in the differentiation of mesenchymal stem cells; thus, blocking its expression induces the activation of thermogenic proteins in different cell models (Scime et al. 2005, Calo et al. 2010, Hakim-Weber et al. 2011). Nevertheless, few descriptions of the $\mathrm{pRb}$ inhibition in differentiated adult human adipose cells are reported. Our group previously observed that EID1 binds and inhibits pRb in 3T3-L1 cells (Lizcano \& Vargas 2010). Here, we demonstrated that EID1 reduced the expression of $\mathrm{pRb}$ in both ADMSCs and human differentiated adipocytes. Additionally, blockage of EID1 expression using a specific siRNA reduced PGC1 $\alpha$ expression, indicating a close functional relationship between these proteins. These findings indicate that the antagonism of EID1 toward $\mathrm{pRb}$ may indirectly increase the levels of PGC1 $\alpha$. The aP2-EID1 expression vector may have therapeutic relevance because EID1 activity may be specific to white fat cells, and the metabolic effects of reducing $\mathrm{pRb}$ may benefit patients classified as obese (Hansen et al. 1999, Fajas et al. 2002). The observed effects of EID1 in adult human fat cells have not been previously described, with current data showing only phenotypic changes in animal models (Hansen et al. 2004a, Fernandez-Marcos \& Auwerx 2010).

In conclusion, EID1 may act in two ways. First, it may modulate mesenchymal cells that are immersed in adipose tissue, affecting tissue metabolism and inducing the beige phenotype in these cells. Secondly, EID1 may play an important role in the transdifferentiation of white adipose cells to more metabolically active adipocytes, such as beige cells. Further research is necessary to determine the role of EID1 in regulating $\mathrm{pRb}$ protein and to assess any beneficial pharmacological effects resulting from the EID1 induction of thermogenic proteins, which may aid in the treatment of individuals with obesity.

\section{Declaration of interest}

The authors declare that there is no conflict of interest that could be perceived as prejudicing the impartiality of the research reported.

\section{Funding}

This work was supported by grant MED 148-2011 from Universidad de La Sabana and grant 123051929210 from Colciencias.

\section{Acknowledgements}

The authors thank Dr Helena Groot and Ivan Martinez for their helpful comments and the members of the Departments of Surgery and Gynecology of the University Clinic of La Sabana.

Published by Bioscientifica Ltd. 


\section{References}

Auffret J, Viengchareun S, Carre N, Denis RG, Magnan C, Marie PY, Muscat A, Feve B, Lombes M \& Binart N 2012 Beige differentiation of adipose depots in mice lacking prolactin receptor protects against high-fat-diet-induced obesity. FASEB Journal 26 3728-3737. (doi:10.1096/fj.12-204958)

Bavner A, Johansson L, Toresson G, Gustafsson JA \& Treuter E 2002 A transcriptional inhibitor targeted by the atypical orphan nuclear receptor SHP. EMBO Reports 3 478-484. (doi:10.1093/embo-reports/ kvf087)

Berry R \& Rodeheffer MS 2013 Characterization of the adipocyte cellular lineage in vivo. Nature Cell Biology 15 302-308. (doi:10.1038/ncb2696)

Calo E, Quintero-Estades JA, Danielian PS, Nedelcu S, Berman SD \& Lees JA $2010 \mathrm{Rb}$ regulates fate choice and lineage commitment in vivo. Nature 466 1110-1114. (doi:10.1038/nature09264)

Cannon B \& Nedergaard J 2004 Brown adipose tissue: function and physiological significance. Physiological Reviews 84 277-359. (doi:10.1152/physrev.00015.2003)

Cypess AM, Lehman S, Williams G, Tal I, Rodman D, Goldfine AB, Kuo FC, Palmer EL, Tseng YH, Doria A et al. 2009 Identification and importance of brown adipose tissue in adult humans. New England Journal of Medicine 360 1509-1517. (doi:10.1056/NEJMoa0810780)

Dali-Youcef N, Mataki C, Coste A, Messaddeq N, Giroud S, Blanc S, Koehl C, Champy MF, Chambon P, Fajas L et al. 2007 Adipose tissue-specific inactivation of the retinoblastoma protein protects against diabesity because of increased energy expenditure. PNAS 104 10703-10708. (doi:10.1073/pnas.0611568104)

van Dijk SJ, Molloy PL, Varinli H, Morrison JL, Muhlhausler BS \& Members of EpiSCOPE 2014 Epigenetics and human obesity. International Journal of Obesity 39 85-97. (doi:10.1038/ijo.2014.34)

Elabd C, Chiellini C, Carmona M, Galitzky J, Cochet O, Petersen R, Pénicaud L, Kristiansen K, Bouloumié A, Casteilla L et al. 2009 Human multipotent adipose-derived stem cells differentiate into functional brown adipocytes. Stem Cells 27 2753-2760. (doi:10.1002/stem.200)

Fajas L, Egler V, Reiter R, Hansen J, Kristiansen K, Debril MB, Miard S \& Auwerx J 2002 The retinoblastoma-histone deacetylase 3 complex inhibits PPAR $\gamma$ and adipocyte differentiation. Developmental Cell 3 903-910. (doi:10.1016/S1534-5807(02)00360-X)

Fernandez-Marcos PJ \& Auwerx J 2010 pRb, a switch between bone and brown fat. Developmental Cell 19 360-362. (doi:10.1016/j.devcel.2010. 08.018)

Hakim-Weber R, Krogsdam AM, Jørgensen C, Fischer M, Prokesch A, Bogner-Strauss JG, Bornstein SR, Hansen JB, Madsen L, Kristiansen K et al. 2011 Transcriptional regulatory program in wild-type and retinoblastoma gene-deficient mouse embryonic fibroblasts during adipocyte differentiation. BMC Research Notes 4 157. (doi:10.1186/ 1756-0500-4-157)

Hallenborg P, Feddersen S, Madsen L \& Kristiansen K 2009 The tumor suppressors pRB and p53 as regulators of adipocyte differentiation and function. Expert Opinion on Therapeutic Targets 13 235-246. (doi:10.1517/14712590802680141)

Hansen JB, Petersen RK, Larsen BM, Bartkova J, Alsner J \& Kristiansen K 1999 Activation of peroxisome proliferator-activated receptor $\gamma$ bypasses the function of the retinoblastoma protein in adipocyte differentiation. Journal of Biological Chemistry 274 2386-2393. (doi:10.1074/jbc.274.4.2386)

Hansen JB, Jørgensen C, Petersen RK, Hallenborg P, De Matteis R, Bøye HA, Petrovic N, Enerbäck S, Nedergaard J, Cinti S et al. 2004a Retinoblastoma protein functions as a molecular switch determining white versus brown adipocyte differentiation. PNAS 101 4112-4117. (doi:10.1073/ pnas.0301964101)

Hansen JB, te Riele H \& Kristiansen K 2004b Novel function of the retinoblastoma protein in fat: regulation of white versus brown adipocyte differentiation. Cell Cycle 3 774-778. (doi:10.4161/ cc.3.6.908)
Harms M \& Seale P 2013 Brown and beige fat: development, function and therapeutic potential. Nature Medicine 19 1252-1263. (doi:10.1038/ nm.3361)

Imai T, Jiang M, Chambon P \& Metzger D 2001 Impaired adipogenesis and lipolysis in the mouse upon selective ablation of the retinoid $\mathrm{X}$ receptor $\alpha$ mediated by a tamoxifen-inducible chimeric Cre recombinase (Cre-ERT2) in adipocytes. PNAS 98 224-228. (doi:10.1073/pnas.011528898)

Khidr L \& Chen PL 2006 RB, the conductor that orchestrates life, death and differentiation. Oncogene 25 5210-5219. (doi:10.1038/sj.onc.1209612)

Kilroy G, Burk DH \& Floyd ZE 2009 High efficiency lipid-based siRNA transfection of adipocytes in suspension. PLOS ONE 4 e6940. (doi:10.1371/journal.pone.0006940)

Lee P, Swarbrick MM \& Ho KK 2013 Brown adipose tissue in adult humans: a metabolic renaissance. Endocrine Reviews 34 413-438. (doi:10.1210/ er.2012-1081)

Lidell ME, Betz MJ, Dahlqvist Leinhard O, Heglind M, Elander L, Slawik M, Mussack T, Nilsson D, Romu T, Nuutila P et al. 2013 Evidence for two types of brown adipose tissue in humans. Nature Medicine 19 631-634. (doi:10.1038/nm.3017)

Lidell ME, Betz MJ \& Enerback S 2014 Two types of brown adipose tissue in humans. Adipocyte 3 63-66. (doi:10.4161/adip.26896)

Lizcano F \& Vargas D 2010 EID1-induces brown-like adipocyte traits in white 3T3-L1 pre-adipocytes. Biochemical and Biophysical Research Communications 398 160-165. (doi:10.1016/j.bbrc.2010.06.034)

MacLellan WR, Xiao G, Abdellatif M \& Schneider MD 2000 A novel $\mathrm{Rb}$ - and $\mathrm{p} 300$-binding protein inhibits transactivation by MyoD. Molecular and Cellular Biology 20 8903-8915. (doi:10.1128/MCB.20.23. 8903-8915.2000)

Mercader J, Ribot J, Murano I, Feddersen S, Cinti S, Madsen L, Kristiansen K, Bonet ML \& Palou A 2009 Haploinsufficiency of the retinoblastoma protein gene reduces diet-induced obesity, insulin resistance, and hepatosteatosis in mice. American Journal of Physiology. Endocrinology and Metabolism 297 E184-E193. (doi:10.1152/ajpendo.00163.2009)

Miyake S, Sellers WR, Safran M, Li X, Zhao W, Grossman SR, Gan J, DeCaprio JA, Adams PD \& Kaelin WG Jr 2000 Cells degrade a novel inhibitor of differentiation with E1A-like properties upon exiting the cell cycle. Molecular and Cellular Biology 20 8889-8902. (doi:10.1128/ MCB.20.23.8889-8902.2000)

Nedergaard J, Bengtsson T \& Cannon B 2011 New powers of brown fat: fighting the metabolic syndrome. Cell Metabolism 13 238-240. (doi:10.1016/j.cmet.2011.02.009)

Nishizawa H, Yamagata K, Shimomura I, Takahashi M, Kuriyama H, Kishida K, Hotta K, Nagaretani H, Maeda N, Matsuda M et al. 2002 Small heterodimer partner, an orphan nuclear receptor, augments peroxisome proliferator-activated receptor $\gamma$ transactivation. Journal of Biological Chemistry 277 1586-1592. (doi:10.1074/jbc.M104301200)

Ohno H, Shinoda K, Spiegelman BM \& Kajimura S 2012 PPAR $\gamma$ agonists induce a white-to-brown fat conversion through stabilization of PRDM16 protein. Cell Metabolism 15 395-404. (doi:10.1016/j.cmet. 2012.01.019)

Onate SA, Tsai SY, Tsai MJ \& O'Malley BW 1995 Sequence and characterization of a coactivator for the steroid hormone receptor superfamily. Science 270 1354-1357. (doi:10.1126/science. 270.5240.1354)

Orbay H, Tobita M \& Mizuno H 2012 Mesenchymal stem cells isolated from adipose and other tissues: basic biological properties and clinical applications. Stem Cells International 2012 461718. (doi:10.1155/2012/ 461718)

Robbins GR, Wen H \& Ting JP 2014 Inflammasomes and metabolic disorders: old genes in modern diseases. Molecular Cell 54 297-308. (doi:10.1016/j.molcel.2014.03.029)

Rodeheffer MS, Birsoy K \& Friedman JM 2008 Identification of white adipocyte progenitor cells in vivo. Cell 135 240-249. (doi:10.1016/ j.cell.2008.09.036)

Rosen ED \& Spiegelman BM 2014 What we talk about when we talk about fat. Cell 156 20-44. (doi:10.1016/j.cell.2013.12.012)

Published by Bioscientifica Ltd. 
Scime A, Grenier G, Huh MS, Gillespie MA, Bevilacqua L, Harper ME \& Rudnicki MA $2005 \mathrm{Rb}$ and p107 regulate preadipocyte differentiation into white versus brown fat through repression of PGC- $1 \alpha$. Cell Metabolism 2 283-295. (doi:10.1016/j.cmet.2005.10.002)

Seale P 2015 Transcriptional regulatory circuits controlling brown fat development and activation. Diabetes 64 2369-2375. (doi:10.2337/ db15-0203)

Seale P, Bjork B, Yang W, Kajimura S, Chin S, Kuang S, Scime A, Devarakonda S, Conroe HM, Erdjument-Bromage H et al. 2008 PRDM16 controls a brown fat/skeletal muscle switch. Nature 454 961-967. (doi:10.1038/nature07182)

Sharp LZ, Shinoda K, Ohno H, Scheel DW, Tomoda E, Ruiz L, Hu H, Wang L, Pavlova Z, Gilsanz V et al. 2012 Human BAT possesses molecular signatures that resemble beige/brite cells. PLoS ONE 7 e49452. (doi:10.1371/journal.pone.0049452)

Sidossis L \& Kajimura S 2015 Brown and beige fat in humans: thermogenic adipocytes that control energy and glucose homeostasis. Journal of Clinical Investigation 125 478-486. (doi:10.1172/JCI78362)

Skurk T, Ecklebe S \& Hauner H 2007 A novel technique to propagate primary human preadipocytes without loss of differentiation capacity. Obesity 15 2925-2931. (doi:10.1038/oby.2007.349)

Spiegelman BM 1998 PPAR- $\gamma$ : adipogenic regulator and thiazolidinedione receptor. Diabetes 47 507-514. (doi:10.2337/diabetes.47.4.507)

Tabbi-Anneni I, Cooksey R, Gunda V, Liu S, Mueller A, Song G, McClain DA \& Wang L 2010 Overexpression of nuclear receptor SHP in adipose tissues affects diet-induced obesity and adaptive thermogenesis. American Journal of Physiology. Endocrinology and Metabolism 298 E961-E970. (doi:10.1152/ajpendo.00655.2009)
Takeshita A, Cardona GR, Koibuchi N, Suen CS \& Chin WW 1997 TRAM-1, a novel 160-kDa thyroid hormone receptor activator molecule, exhibits distinct properties from steroid receptor coactivator-1. Journal of Biological Chemistry 272 27629-27634. (doi:10.1074/jbc.272.44.27629)

Vitali A, Murano I, Zingaretti MC, Frontini A, Ricquier D \& Cinti S 2012 The adipose organ of obesity-prone $\mathrm{C} 57 \mathrm{BL} / 6 \mathrm{~J}$ mice is composed of mixed white and brown adipocytes. Journal of Lipid Research 53 619-629. (doi:10.1194/jlr.M018846)

Wen $\mathrm{H} \&$ Ao S 2001 Identification and characterization of a novel human cDNA encoding a $21 \mathrm{kDa}$ pRb-associated protein. Gene 263 85-92. (doi:10.1016/S0378-1119(00)00585-0)

Wu J, Bostrom P, Sparks LM, Ye L, Choi JH, Giang AH, Khandekar M, Virtanen KA, Nuutila P, Schaart G et al. 2012 Beige adipocytes are a distinct type of thermogenic fat cell in mouse and human. Cell $\mathbf{1 5 0}$ 366-376. (doi:10.1016/j.cell.2012.05.016)

Wu J, Cohen P \& Spiegelman BM 2013 Adaptive thermogenesis in adipocytes: is beige the new brown? Genes and Development 27 234-250. (doi:10.1101/gad.211649.112)

Zeve D, Tang W \& Graff J 2009 Fighting fat with fat: the expanding field of adipose stem cells. Cell Stem Cell 5 472-481. (doi:10.1016/j.stem.2009. 10.014)

Zhu Y, Kan L, Qi C, Kanwar YS, Yeldandi AV, Rao MS \& Reddy JK 2000 Isolation and characterization of peroxisome proliferator-activated receptor (PPAR) interacting protein (PRIP) as a coactivator for PPAR. Journal of Biological Chemistry 275 13510-13516. (doi:10.1074/jbc.275. 18.13510)

Zufferey R, Donello JE, Trono D \& Hope TJ 1999 Woodchuck hepatitis virus posttranscriptional regulatory element enhances expression of transgenes delivered by retroviral vectors. Journal of Virology 73 2886-2892.

Received in final form 17 November 2015

Accepted 4 December 2015

Accepted Preprint published online 7 December 2015
(C) 2016 Society for Endocrinology Printed in Great Britain 